
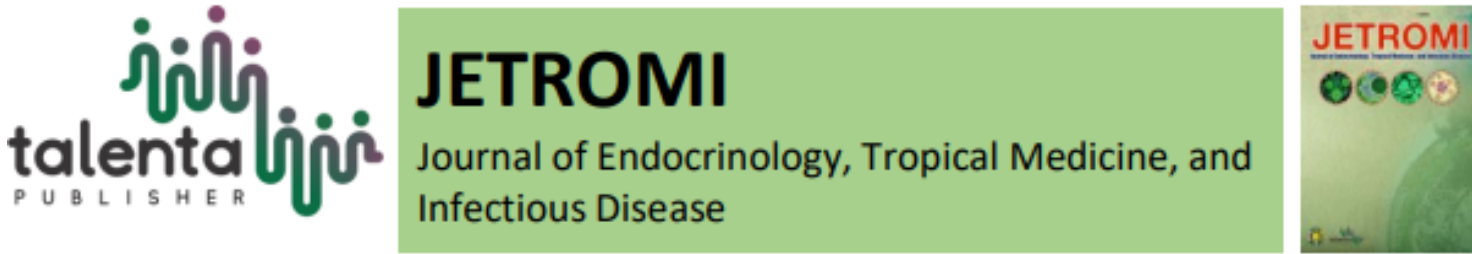

\title{
Postpartum Thyroiditis: A Case Report
}

\author{
Jessica Patricia Pangaribuan*, Santi Syafril \\ Department of Internal Medicine, Faculty of Medicine, University of Sumatera Utara, Medan, North \\ Sumatera, Indonesia
}

\begin{abstract}
:
Background: Postpartum thyroiditis (PPT) is a thyroid dysfunction syndrome that is temporary or permanent that occurs 6 month until 1 year after giving birth or abortion. The occurrence of postpartum thyroiditis is $5-10 \%$ of postpartum women in the world. It is caused by an inflammation of the thyroid gland which leads to a destruction of the thyroid follicle and proteolysis of thyroglobulin.

Case Presentation: A woman 31 years old was admitted to the hospital complaining of enlargement on her neck. The patient said the enlargement keeps getting larger and she also complained of a feeling of something stuck in the throat and hoarse voice. The patient has just given birth to her second child 5 months ago. From a hematologic examination, radiologic, and blood culture, the patient was diagnosed with Postpartum Thyroiditis. The patient was given Euthyrox therapy and will undergo repeated evaluation after 1 month of the therapy.
\end{abstract}

Conclusion: We reported a case of Postpartum Thyroiditis that was treated comprehensively, and showed a good prognosis.

Keyword: Postpartum Thyroiditis

\begin{abstract}
ABSTRAK:
Latar Belakang: Tiroiditis postpartum (PPT) adalah sindrom disfungsi tiroid yang bersifat sementara atau permanen yang terjadi 6 bulan sampai 1 tahun setelah melahirkan atau aborsi. Di dunia terjadinya tiroiditis postpartum adalah $5-10 \%$. Hal ini disebabkan oleh peradangan kelenjar tiroid yang menyebabkan penghancuran folikel tiroid dan proteolisis tiroglobulin.
\end{abstract}

*Corresponding author at: Faculty of Medicine, Universitas Sumatera Utara, Medan, North Sumatera, Indonesia

E-mail address: 93jessicapangaribuan@gmail.com 
Presentasi Kasus: Seorang wanita usia 31 tahun, dirawat di rumah sakit karena mengeluh pembesaran di lehernya. Pasien mengatakan pembesaran terus semakin besar dan dia juga mengeluhkan perasaan sesuatu yang tersangkut di tenggorokan dan suara serak. Pasien baru saja melahirkan anak keduanya 5 bulan yang lalu. Dari pemeriksaan hematologis, radiologi, dan darah, pasien didiagnosis menderita Tiroiditis Postpartum. Pasien diberikan terapi Euthyrox dan akan menjalani evaluasi berulang setelah 1 bulan terapi.

Kesimpulan: Dilaporkan kasus Tiroiditis Postpartum yang diobati secara komprehensif, dan menunjukkan prognosis yang baik.

\section{Kata Kunci : Tiroiditis Postpartum}

Received 25 January 2021 | Revised 14 May 2021 | Accepted 31 May 2021

\section{Introduction}

Postpartum thyroiditis (PPT) is a thyroid dysfunction syndrome that is temporary or permanent that occurs 1 year after giving birth or abortion. The occurrence of postpartum thyroiditis is 5 $10 \%$ of postpartum women in the world. This disease commonly occurs in women that have a high serum concentration of thyroid peroxidase antibody during their first-trimester pregnancy or immediately after giving birth. [1-2] This condition more commonly occurs in patients that have another autoimmune disease, such as diabetes mellitus type 1, or with a family history of thyroid autoimmune disease. This condition could cause a hyperthyroid state which may be followed by a hypothyroid state, and this condition also could occur repeatedly on the next pregnancy, even it could give a risk to develop a permanent hypothyroid in the future [3-4]. Thus, it is necessary to improve the identification of risk factors, clinical manifestations, and prognosis of postpartum thyroiditis.

\section{Case Presentation}

A 31 years old woman, was referred to the H. Adam Malik central public hospital on December 22nd, 2020, with chief complaints of a neck swelling. This was experienced by the patient for \pm 7 days before being admitted to the hospital. Initially, the patient complained of a feeling of something stuck in the throat and a hoarse voice. There's also a feeling of fatigue and easily getting tired when doing an activity that occurred within these 7 days. The history of contact or exposure to Covid-19 patients within 14 days is denied. The patient had just given birth to her second child 5 months ago, and the baby's weight was $3,8 \mathrm{~kg}$. There is no diabetes mellitus history on the patient.

From the examination, the patient with bodyweight $65 \mathrm{~kg}$ and height $160 \mathrm{~cm}$ with BMI 25.39 $\mathrm{Kg} / \mathrm{m} 2$ were overweight. The pulse rate was 84 times/min, blood pressure of $120 / 70 \mathrm{mmHg}$, a respiratory rate of 18 breaths $/ \mathrm{min}$, a temperature of $36.7 \mathrm{oC}$. The physical examination of the neck 
showed there was a goiter grade 2 , an enlargement of the thyroid, rubbery consistency, mobile (), the surface was smooth with indistinct margin, tenderness (-). Other physical examinations were within normal limits. A complete blood count showed the results $\mathrm{Hb} 14.1 \mathrm{~g} / \mathrm{dL}$, leukocytes $7,640 / \mu \mathrm{L}$, platelets of $350,000 / \mu \mathrm{L}$, neutrophils $51.5 \%$, and lymphocytes $37.6 \%$. The patient's adrandom blood glucose was $255 \mathrm{mg} / \mathrm{dL}$. The electrolyte, sodium $137 \mathrm{mEq} / \mathrm{L}$, potassium $4 \mathrm{mEq} / \mathrm{L}$, and chloride of $100 \mathrm{mEq} / \mathrm{L}$. The thyroid function lab result showed TSH 75,41; FT4 0,46; and T3 0,53. From the electrocardiogram, it was found sinus rhythm. From the chest radiograph, it was found within normal limits. The patient was then diagnosed with Postpartum Thyroiditis dan DMT2. The patient was given Euthyrox $1 \times 100 \mathrm{mcg}$ and Lantus 10 unit subcutaneously at night.

On the next day, patient's fasting blood glucose of $224 \mathrm{mg} / \mathrm{dL}$, a 2-hour postprandial blood glucose of $355 \mathrm{mg} / \mathrm{dL}, \mathrm{HbA} 1 \mathrm{c}$ of $9 \%$, total cholesterol of $312 \mathrm{mg} / \mathrm{dL}$, triglycerides of $232 \mathrm{mg} / \mathrm{dL}$, HDL of $40 \mathrm{mg} / \mathrm{dL}$ and LDL of $231 \mathrm{mg} / \mathrm{dL}$. The USG examination of the thyroid showed bilateral thyroiditis. Furthermore, an FNAB examination was done and the result showed subacute thyroiditis. The patient was then diagnosed with Postpartum Thyroiditis, DMT2 dan secondary dyslipidemia. The patient was then given a $2300 \mathrm{kcal}$ diet DM, Euthyrox 1x100 mcg, Lantus injection $10 \mathrm{IU}$ SC, and additional therapy of simvastatin 1x $20 \mathrm{mg}$. The patient was planned to undergo the next evaluation of TSH in 1 month after the euthyrox therapy and would be followed up with the fasting blood glucose and 2-hour postprandial blood glucose. The patient was then discharged from the hospital on the 24th of December 2020.

\section{Discussion}

Postpartum thyroiditis (PPT) is an inflammation of the thyroid follicle which occurs few months until a year after giving birth or abortion. Postpartum thyroiditis is often called painless postpartum thyroiditis or subacute lymphocytic thyroiditis. The clinical symptoms of postpartum thyroiditis were very typical, that is started with thyrotoxicosis and then followed with a hypothyroid symptom. The patient incidence with only a hyperthyroid symptom ranges from 20 - 40 percent, while 40 - 50 percent have only hypothyroidism, and the remainder experiences these two-phase symptoms. Some women do not restore normal endogenous thyroid function after the initial episode of hypothyroidism [5-6].

The onset of thyrotoxicosis ranges from 1 to 6 months after delivery, usually around the 3rd month, and typically lasts for 1-2 months. It is the result of the release of stored thyroid hormones due to the destruction of thyrocytes and has a transitory and self-limiting nature [1-2]. The symptom of the hypothyroid condition usually is mild and most are asymptomatic. The most common complaints are tiredness, rapid heart rate, irritability, anxiety, tremor of the hands, and sleep disorders. It is important to differentiate between the thyrotoxic phase of PPT and relapse or onset of Graves' disease in the postpartum period. Whereas this condition is similar to postpartum depression, thus it is sometimes difficult to differentiate it [7]. 
The hypothyroid phase could occur from month 4 to month 8 after giving birth and would continue to occur throughout $4-6$ months. This phase occurs when the storage of thyroglobulin runs out and no proteolysis occurred so that the T3 and T4 start to decrease. Patients usually complain of tiredness, poor concentration, memory loss, constipation, pain in muscles and joints, weight gain. Most patients were diagnosed within this phase instead of the hyperthyroid phase [1].

The diagnosis of postpartum thyroiditis was made if there is a suspicion on a patient 1 year after giving birth which is based on clinical symptoms, whether it is a hyperthyroid phase or hypothyroid phase. Also, if there is an enlargement of the neck even though the patient is asymptomatic. In that condition, we could do the examination of thyroid function which are TSH and FT4, to make sure whether there is a disorder of the thyroid function. If the examination result showed hyperthyroid, it is should be continued with the examination of TRAb. On patients with the thyroid function examination result that showed hypothyroid, it is should be continued with the examination of TPO-Ab even though this examination still couldn't differentiate it from the Hashimoto thyroiditis [4].

The ultrasonography examination is also routinely performed on postpartum thyroiditis patients. The presentation of diffuse or focal hypoechogenicity due to lymphocytic infiltration and destructive changes are most commonly found in this case. Vascularization of the gland is greatly attenuated. In women with PPT and TPO Ab, the ultrasound image is subacute autoimmune thyroiditis. Fine needle aspiration biopsy is not a routine diagnostic method of the disease. The histologic analysis shows focal or diffuse lymphocytic infiltrate around the destroyed follicles, and giant multinucleated cells are observed surrounding the colloid extravasates [1-2].

According to American Thyroid Association (ATA) and the Endocrine Society, the therapy of patients with postpartum thyroiditis can be divided based on the clinical of the patient, which is patient without symptoms, patient with hyperthyroid that shows symptoms, and patient with hypothyroid that shows symptoms. Postpartum thyroiditis patients which are asymptomatic do not need medication, whether the phase is hyperthyroid or hypothyroid. The evaluation of thyroid function should be performed every four to eight weeks to assess the improvement of the patient's thyroid hormone condition. Patients with hyperthyroid symptoms such as palpitation, tiredness, heat intolerance, and nervousness, would be given a beta-blocker such as propranolol with a dosage of $40-120 \mathrm{mg}$ a day until the thyroid hormone level becomes normal. Patients with hypothyroid symptoms or patients without symptoms with TSH levels above $10 \mathrm{mU} / \mathrm{L}$ should be medicated with T4 (levothyroxine) with a dosage of 50 - $100 \mathrm{mcg}$ a day. It should be evaluated again after four to six weeks after initiation of therapy to adjust the dosage. The duration of thyroid hormone therapy is still not certain, but many experts consider the therapy would be given for 12 months. Eventually, the decision to stop thyroid hormone therapy should be based on the patient's clinical presentation. Women that have been recovered should be evaluated for the TSH serum every year, particularly within 5 to 10 years after the initial diagnosis [8-9]. 
Until these days, no therapy prevents the occurrence of postpartum thyroiditis. There is some research about giving levothyroxine and iodine to pregnant women with high TPO Ab but there's no significant difference. Therefore, it is necessary to examine thyroid function routinely every first childbirth to anticipate the occurrence of postpartum thyroiditis and prevent a disorder of the baby's thyroid function.

\section{Conclusion}

We have reported a case of postpartum thyroiditis, DMT2, and secondary dyslipidemia. This case showed that postpartum thyroiditis is a disease that commonly occurs in the first year after giving birth. Appropriate therapy will increase the number of remissions; thus it is necessary to evaluate until the thyroid function of the patient reaching normal level.

\section{REFERENCES}

[1] Muller AF, Drexhage HA, Berghout A. Postpartum thyroiditis and autoimmune thyroiditis in women of childbearing age: recent insights and consequences for antenatal and postnatal care. Endocr Rev vol.22, pp:605-30. 2001

[2] Kologlu M, Fung H, Darke C, et al. Postpartum thyroid dysfunction and HLA status. Eur J Clin Invest vol.20, p:56. 1990

[3] Alvarez-Marfany M, Roman SH, Drexler AJ. Long-term prospective study of postpartum thyroid dysfunction in women with insulin-dependent diabetes mellitus. J Clin Endocrinol Metab vol.79, pp:10-6. 1994

[4] Lazarus JH, Premawardhana LDKE. Postpartum Thyroiditis. In: Weetman AP, ed. Contemporary Endocrinology: Autoimmune Diseases in Endocrinology. Totowa, New Jersey: Humana Press pp.177-92. 2008

[5] Azizi F. The occurrence of permanent thyroid failure in patients with subclinical postpartum thyroiditis. Eur J Endocrinol vol.153, pp:367. 2005

[6] Tachi J, Amino N, Tamaki H, et al. Long term follow-up and HLA association in patients with postpartum hypothyroidism. J Clin Endocrinol Metab pp. 66:480. 1988

[7] De Groot L, Abalovich M, Alexander EK, et al. Management of thyroid dysfunction during pregnancy and postpartum: An Endocrine Society Clinical Practice Guideline. J Clin Endocrinol Metab vol.97, no.8, pp:2543-65. 2012

[8] Alexander EK, Pearce EN, Brent GA, et al. 2017 Guidelines of the American Thyroid Association for the Diagnosis and Management of Thyroid Disease During Pregnancy and the Postpartum. Thyroid vol.27,pp.315. 2017

[9] De Groot L, Abalovich M, Alexander EK, et al. Management of thyroid dysfunction during pregnancy and postpartum: an Endocrine Society clinical practice guideline. J Clin Endocrinol Metab vol.97, pp.2543. 2012 
[10] Stagnaro-Green A, Abalovich M, Alexander E, et al. Guidelines of the American Thyroid Association for the Diagnosis and Management of Thyroid Disease During Pregnancy and Postpartum. Thyroid vol.21, no.10, pp:1081-125. 2011 